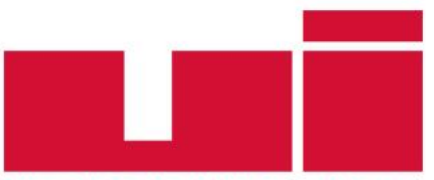

ULUSLARARASIILIȘKiLER

Akademik Dergi

Yayın ilkeleri, izinler ve abonelik hakkında ayrıntılı bilgi:

E-mail: bilgi@uidergisi.com.tr

Web: www.uidergisi.com.tr

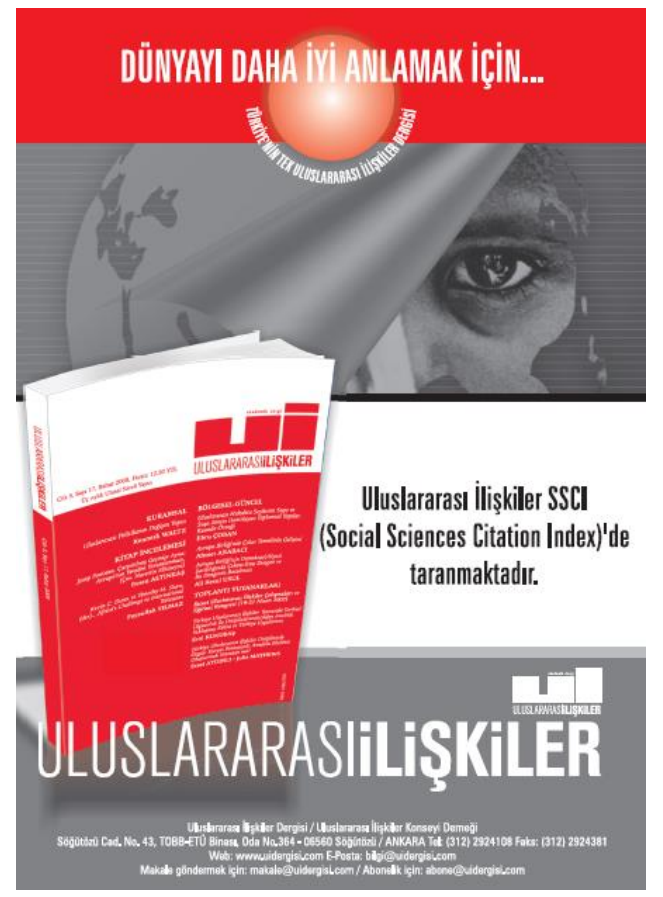

\title{
Kapsamlı Ortak Eylem Planı ve Irran'ın Nükleer Programının Geleceği
}

\author{
Murat BAYAR* \\ * Yrd. Doç. Dr., Siyaset Bilimi Bölümü, Ankara Sosyal \\ Bilimler Üniversitesi
}

Bu makaleye atıf icin: Bayar, Murat, "Kapsamlı Ortak Eylem Planı ve Iran'ın Nükleer Programının Geleceği”, Uluslararası Illişkiler, Cilt 13, Sayı 51, 2016, s. 81-97.

Bu makalenin tüm hakları Uluslararası İlişkiler Konseyi Derneği'ne aittir. Önceden yazılı izin alınmadan hiç bir iletişim, kopyalama ya da yayın sistemi kullanılarak yeniden yayımlanamaz, çoğaltılamaz, dağıtılamaz, satılamaz veya herhangi bir şekilde kamunun ücretli/ücretsiz kullanımına sunulamaz. Akademik ve haber amaçlı kısa alıntılar bu kuralın dışındadır.

Aksi belirtilmediği sürece Uluslararası Illişkiler'de yayınlanan yazılarda belirtilen fikirler yalnızca yazarına/yazarlarına aittir. UİK Derneğini, editörleri ve diğer yazarları bağlamaz. 


\title{
Kapsamlı Ortak Eylem Planı ve İran'ın Nükleer Programının Geleceği
}

\author{
Murat BAYAR \\ Yrd. Doç. Dr., Siyaset Bilimi Bölümü, Siyasal Bilgiler Fakültesi, Ankara Sosyal Bilimler Üniversitesi, Ankara. \\ E-posta: murat.bayar@asbu.edu.tr
}

\begin{abstract}
ÖZET
Neden devletler nükleer silah programı başlatırlar ve hangi koşullarda bu programları sona erdirirler? Bu soruların yanıtlanması, AB3+3'ün Temmuz 2015'de İran ile imzaladığı Kapsamlı Ortak Eylem Planı’nın (KOEP) hedeflerine ulaşma potansiyelinin değerlendirilmesi açısından önem taşımaktadır. Karşılaştırmalı vaka analizleri nükleer silah programlarının sona erdirilmesindeki en belirleyici etkenler arasında ulusal güvenlik risklerinin azalmasının ve rejim değişikliğinin bulunduğunu ortaya koymaktadır. Öte yandan, yaptırımlar ve arz taraflı kısıtlar nükleer silah geliştirmeyi sadece geciktirmektedir. Makalenin vardığı sonuç, yeni tehditler sebebiyle bölgesel güvenlik risklerinde artış yaşayan İran'ın nükleer silah geliştirme motivasyonunu ve koşullarını ortadan kaldırmada KOEP'in yetersiz olduğu şeklindedir.
\end{abstract}

Anahtar Kelimeler: İran, Nükleer Silah, KOEP, Yaptırım, Ulusal Güvenlik.

\section{The Joint Comprehensive Plan of Action and the Future of Iran's Nuclear Program}

\begin{abstract}
Why do states start nuclear weapons programs and under which conditions do they terminate these programs? Answering these questions are essential to asses the potential of the Joint Comprehensive Plan of Action (JCPOA), which was signed by EU3+3 and Iran in July 2015, to achieve its objectives. Comparative case analyses indicate that the primary factors in termination of nuclear weapon programs include reduction in national security risks and regime change. However, sanctions and supply-side limitations only delay the acquisition of nuclear weapons. This article concludes that JCPOA falls short of eliminating the motives and conditions of Iran to develop nuclear weapons, since new threats have worsened the regional security environment for Iran.
\end{abstract}

Keywords: Iran, Nuclear Weapon, JCPOA, Sanctions, National Security. 
İran ile Avrupa Birliği 3+3 $3^{1} 14$ Temmuz 2015'de Viyana'da Kapsamlı Ortak Eylem Planı'nı (KOEP) (Joint Comprehensive Plan of Action) imzaladılar. KOEP temel olarak İran'ı nükleer silah (NS) geliştirme eşiğinden uzak tutmayı amaçlamaktadır. ${ }^{2} 2016$ yılında yürürlüğe giren bu detaylı plan hedefine ulaştığı takdirde, nükleer silahlanmayı önlemede yaptırımların askeri yöntemlerden daha etkili olduğu tezine güçlü bir destek sağlayabilecektir.

$\mathrm{Bu}$ makale karşılaştırmalı vaka analizi yöntemiyle KOEP'in hedefine ulaşma potansiyelini incelemektedir. $\mathrm{Bu}$ incelemede temel soru, devletlerin neden NS programları başlattıkları ve hangi koşullarda bu programları sona erdirdikleridir. Söz konusu sebepler ve koşullar tespit edildiği takdirde, KOEP'in İran'ı nükleer silah geliştirme eşiğinden uzak tutma potansiyeli daha iyi anlaşılabilecektir.

\section{Nükleer Yayılma ve Nükleer İptal}

Neden bazı devletler NS programlarını sona erdirirken, hatta mevcut silahlarını imha ederken, diğer devletler bu programları yoğun yaptırımlara ve baskılara rağmen sürdürürler? $\mathrm{Bu}$ soru, $\mathrm{AB}$ 3+3'ün İran ile imzaladığı KOEP'in hedefine ulaşma potansiyelini incelemek açısından kritik öneme sahiptir. Bazı çalışmalar NS programlarının sona erdirilmesindeki en önemli etkenlerin yaptırımlar ve arz taraflı kısıtlar olduğunu öne sürmektedir. ${ }^{3}$ Buna karşın, Kore Demokratik Halk Cumhuriyeti (Kuzey Kore) düşük gelir düzeyine ve uzun yıllar ağır yaptırımlara maruz kalmasına rağmen 2006 yılında NS geliştirmeyi başarmıştır. ${ }^{4}$ Diğer yandan, İsrail'in 1981'de Irak'ın Osirak nükleer reaktörüne gerçekleştirdiği saldırı sonrasında Irak'ın NS programını durdurmak yerine hızlandırmış olması, sınırlı önleyici saldırıların istenilen sonucu almadaki etkinliğine de şüphe düşürmektedir.

NS geliştirmede esas olarak iki safha olduğu öne sürülebilir: ${ }^{5}$ (1) NS programının başlatılması ve (2) NS elde edilmesi (nükleer yayılma). ${ }^{6} \mathrm{Bu}$ makale söz konusu aşamaları ele alırken çeşitli sebeplerden dolayı NS programının sonlandırıldığı ve elde edilmişse nükleer silahların imha edildiği (nükleer iptal) vakaları da incelemektedir. Nükleer yayılma ve nükleer iptal vakaları Tablo 1'de gösterilmektedir.

Tablo 1 ağırlıklı olarak Jo ve Gartzke ile Levite’ın çalışmalarına dayanmakla birlikte bazı farklılıklar içermektedir.7 Öncelikle, adı geçen çalışmalarda Belarus, Kazakistan ve Ukrayna bir dönem NS devleti olarak kabul edilmektedirler. Bu sınıflandırmanın sebebi, Sovyetler Birliği (SSCB)

1 Almanya, Fransa ve İngiltere, Amerika Birleşik Devletleri (ABD), Çin, Rusya Federasyonu (RF).

2 JCPOA (Joint Comprehensive Plan of Action), 14 Temmuz 2015, s.1, http://eeas.europa.eu/statements-eeas/ docs/iran_agreement/iran_joint-comprehensive-plan-of-action_en.pdf (Erişim Tarihi: 22 Temmuz 2015).

3 Örnek olarak bkz. Benjamin A.Most ve Harvey Starr, Inquiry, Logic and International Politics, Columbia, University of South Carolina Press, 1989; Randolph M.Siverson ve Harvey Starr, "Opportunity, Willingness, and the Diffusion of War", American Political Science Review, Cilt 84, No.1, 1990, s.47-67.

4 World Bank, 25 Mayıs 2016, http://data.worldbank.org/country/korea-democratic-republic (Erişim Tarihi: 25 Mayıs 2016).

5 Dong-Joon Jo ve Erik Gartzke, "Determinants of Nuclear Weapons Proliferation", Journal of Conflict Resolution, Cilt 51, No.1, 2007, s.167-194.

6 Jo ve Gartzke NS elde edilmesinde satın alma ve hırsızlık olasılıklarını dışarıda bırakmıştır.

7 Ariel E. Levite, "Never Say Never Again”, International Security, Cilt 27, No.3, 2002, s.59-88; Dong-Joon Jo ve Erik Gartzke, Codebook and Data Notes for "Determinants of Nuclear Weapons Proliferation: A Quantitative Model. 2006, http://www.columbia.edu/ eg589/ (Erişim Tarihi: 10 Nisan 2015). 
dağıldığında bağımsızlığını ilan eden söz konusu devletlerin, toprakları üzerinde eski Sovyet nükleer füzelerini barındırmış ve daha sonra Rusya Federasyonu'na (RF) teslim etmiş olmalarıdır. ${ }^{8}$ Ancak, bu devletlerin nükleer silahları kendilerinin geliştirmediğini ve hiçbir aşamada nükleer kodlara sahip olmadıklarını not etmek gerekmektedir. ${ }^{9} \mathrm{Bu}$ makale, bir devletin gerçekte sahip olmadığı bir kapasiteden ve güçten vazgeçmesinin söz konusu olamayacağı mantığından hareketle, Belarus, Kazakistan ve Ukrayna'yı Tablo l'e dâhil etmemektedir.

Tablo 1: Nükleer Yayılma ve Nükleer İptal Vakaları (alfabetik sıralı)

\begin{tabular}{|c|c|c|c|}
\hline Nükleer Yayılma & \multicolumn{2}{|c|}{ Nükleer İptal } & \multirow[b]{2}{*}{$\begin{array}{l}\text { Belirsiz } \\
\text { Vakalar }\end{array}$} \\
\hline $\begin{array}{l}\text { NS Elde Etti ve Muhafaza } \\
\text { Etti }\end{array}$ & $\begin{array}{l}\text { NS Geliştirdi } \\
\text { Ama İmha Etti }\end{array}$ & $\begin{array}{c}\text { NS Programinı Sona } \\
\text { Erdirdi }\end{array}$ & \\
\hline ABD & Güney Afrika & Almanya & Cezayir \\
\hline Çin & & Arjantin & Endonezya \\
\hline Fransa & & Brezilya & Hollanda \\
\hline Hindistan & & Güney Kore & Norveç \\
\hline İngiltere & & Irak & Romanya \\
\hline İsrail & & İsveç & Yugoslavya \\
\hline Kuzey Kore & & İsviçre & \\
\hline Pakistan & & İtalya & \\
\hline \multirow[t]{4}{*}{$\mathrm{SSCB} / \mathrm{RF}$} & & Japonya & \\
\hline & & Libya & \\
\hline & & Misir & \\
\hline & & Tayvan & \\
\hline
\end{tabular}

İkinci olarak, Levite Avustralya ve Kanada’yı “NS Programını Sona Erdirdi” vakaları arasında değerlendirdiği halde Jo ve Gartzke bu ülkelerin kendi NS programları olmadığını, ancak diğer devletlerle bu alanda işbirliği yaptıklarını belirtmiştir. ${ }^{10} \mathrm{Bu}$ sebeple, adı geçen iki ülke Tablo 1'de gösterilmemiştir. Son olarak, literatürdeki veri yetersizliği ve tutarsızlı̆̆ sebebiyle "Belirsiz Vakalar" Tablo 1'de ayrı gösterilmişlerdir. Mısır ve Libya ise Levite'ın ve Cirincione'nin analizlerine paralel olarak Tablo 1'e dâhil edilmişlerdir. ${ }^{11}$

8 Levite, "Never Say Never Again".

9 Miller, Ukrayna nükleer silahların kontrolünü ele geçirmek için girişimde bulunsaydı Rus saldırısına maruz kalabilirdi ve bu da Ukrayna'nın NS sahibi olma motivasyonuna (RF'ye karşı güvenlik sağlama) tezat teşkil ederdi görüşündedir. Steven E. Miller, "The Case Against a Ukrainian Nuclear Deterrent”, Foreign Affairs, Cilt 72, No.3, 1993, s.67-80.

10 Örneğin, Kanada ABD’nin NS programı Manhattan Projesi'ne katkıda bulunmuştur. Levite, "Never Say Never Again"; Jo ve Gartzke, Codebook and Data Notes.

11 Cirincione Libya'nın NS programını daha önceden iddia edildiği gibi 1980'lerin sonlarında değil, Aralık 2003 'te sona erdirdiğini not etmektedir. Joseph Cirincione, Bomb Scare: The History and Future of Nuclear Weapons, New York, Columbia University Press, 2007. 


\section{Neden Devletler Nükleer Silah Programı Başlatırlar?}

Teorik olarak, devletlerin NS programlarını iptal etme kararlarında, bu programı başlatmalarına yol açan motivasyonların ve koşulların kısmen veya tamamen ortadan kalkması önemli rol oynayabilir. Öte yandan, söz konusu sebeplerin sürmesi yaptırımların ve diplomasinin hedeflenen sonucu alma (nükleer yayılmayı engelleme veya geciktirme) başarısını etkileyebilir. Her iki durumda da devletlerin neden NS programı başlattıkları sorusunun yanıtlanması kritik önem arz etmektedir. Bu soruyu yanıtlamayı amaçlayan zengin bir literatür bulunmaktadır. ${ }^{12}$ Söz konusu literatüre dayanarak devletlerin NS programı başlatma ve edinme yılları Tablo 2'de verilmektedir.

Tablo 2: Devletlerin Nükleer Silah Programı Başlatma ve Edinme Yılları (tarih sıralı)

\begin{tabular}{|l|c|c|}
\hline \multicolumn{1}{|c|}{ Devlet } & NS Programı Başlangıç Yılı & NS Edinme Yllı \\
\hline İngiltere & 1941 & 1952 \\
\hline ABD & 1942 & 1945 \\
\hline SSCB/RF & 1943 & 1949 \\
\hline Fransa & 1954 & 1960 \\
\hline İsrail & 1955 & 1966 \\
\hline Çin & 1956 & 1964 \\
\hline Hindistan & 1964 & $1974 / 1988$ \\
\hline Güney Afrika & 1971 & 1979 \\
\hline Pakistan & 1972 & 1987 \\
\hline Kuzey Kore & 1982 & 2006 \\
\hline
\end{tabular}

Bir uluslararası ilişkiler teorisi olarak Realizm, ulusal güvenliği temel alan yaklaşımı ile NS çalışmalarına etkili açıklamalar getirmektedir. Kronolojik olarak, İngiltere ve ABD NS programlarını savaş halinde oldukları Nazi Almanya'sının ve Emperyal Japonya’nın konvansiyonel ve potansiyel nükleer silahlarının doğurduğu güvenlik riskleri karşısında başlatmışlardır. ${ }^{13} \mathrm{ABD}$ 1945 yılında Hiroşima ve Nagazaki'de nükleer gücünü dünyaya ilan ettikten sonra SSCB NS geliştirmeyi bir numaralı önceliği yapmıştır. Söz konusu sebep-sonuç ilişkisinin kurulmasında SSCB lideri Josef Stalin'in Sovyet bilim adamlarına verdiği, "Sizden tek bir isteğim var yoldaşlar... Bize atom silahlarını mümkün olan en kısa zamanda sağlayınız. Biliyorsunuz Hiroşima dünyayı sarstı. Denge bozuldu. Bombayı verin, bizi büyük bir tehlikeden uzak tutacaksınız" emrinin vurgulanması gerekmektedir. ${ }^{14}$

12 Örnek olarak bkz. Scott D. Sagan, "Why Do States Build Nuclear Weapons? Three Models in Search of a Bomb", International Security, Cilt 21, No.3, 1996/97, s.54-86; T.V. Paul, Power versus Prudence: Why Nations forgo Nuclear Weapons, Montreal, McGill-Queens University Press, 2000; Kurt M. Campbell ve Robert J. Einhorn, "Avoiding the Tipping Point: Concluding Observations", Kurt M. Campbell, Robert J. Eihnorn ve Mitchell B. Reiss (der.), The Nuclear Tipping Point: Why States Reconsider Their Nuclear Choices, Washington, D.C., Brookings Institution Press, 2004, s.317-45; Jacques E.C. Hymans, The Psychology of Nuclear Proliferation, Cambridge, Cambridge University Press, 2006.

13 Almanya program başlangıcı 1941, Japonya program başlangıcı 1943 yılıdır. Sagan, "Why Do States Build Nuclear Weapons?"; Jo ve Gartzke, "Determinants of Nuclear Weapons Proliferation"; Kyle Beardsley ve Victor Asal, "Winning the Bomb", Journal of Conflict Resolution, Cilt 53, No.2, 2009, s.278-301.

14 Lavrent'yeva in "Stroiteli novogo mira", V mire knig, No.9, 1970'den aktaran David Holloway, The Soviet Union and the Arms Race, New Haven, Yale University Press, 1980. 
Nükleer silahlanmanın daha fazla nükleer yayılma doğurduğu tezini doğrularcasına, ${ }^{15}$ Fransa, Çin, Hindistan, Pakistan, İsrail, Güney Afrika ve Kuzey Kore NS programlarını ciddi ulusal güvenlik riskleri karşısında başlatmışlardır. ${ }^{16}$ Bu tehditler Fransa için SSCB, Çin için ABD (özellikle 1950-53 Kore Savaşı'ndan sonra), Hindistan için Çin (1962 Çin-Hint Savaşı), Pakistan için Hindistan (sınır anlaşmazlıkları), İsrail için Arap komşularıyla savaşlar (özellikle, 1955'de nükleer çalışmalara başlayan Mısır ile), Güney Afrika için komşu ülkelerdeki Sovyet destekli Küba milis güçleri ve Kuzey Kore için yine $\mathrm{ABD}$ olarak belirtilebilir. Bu vakaların istisnasız hepsinde, tehdit algılayan ülkenin NS programını başlattığı yılda tehdit kaynağı ülke NS sahibidir veya NS araştırmaları yapmaktadır. ${ }^{17}$

Realist model aynı zamanda, Fransa ve İngiltere’nin Kuzey Atlantik Antlaşması Örgütü/Paktı (North Atlantic Treaty Organization-NATO) üyesi oldukları ve 1949'da Amerikan nükleer savunma şemsiyesialtına girdiklerihalde NS programlarınıneden devam ettirdiklerine de açıklama getirmektedir. Şöyle ki, bu iki ülkenin söz konusu tarihlerde Avrupa dışında toprakları/kolonileri bulunduğundan ABD'den bağımsız stratejik çıkarları mevcuttur ve ABD'nin nükleer savunma şemsiyesine tam olarak güven duymamaktadırlar. Buna bağlı olarak, Fransa ve İngiltere'nin ulusal güvenliklerini korumanın yanı sıra bağımsız dış politikalarını sürdürmek için NS elde etme motivasyonları doğmuştur. Söz konusu sebep-sonuç ilişkisini destekleyen çarpıcı bir anekdotta Fransa Cumhurbaşkanı Charles de Gaulle 1959'da, ABD Başkanı Dwight Eisenhower’a yönelik olarak, “Onlar [gelecekteki Amerikan başkanları] Berlin, Brüksel ve Paris’in hür kalabilmesi için Amerikan şehirlerinin yok olması riskini göz önüne alacaklar mıdır?" sorusunu sormuş ve "Sadece bu şekilde [NS sahibi olarak] bizim, her şeyden önemli gördügümüz savunma ve dış politikalarımız bağımsız kalabilir” demiştir. ${ }^{18}$

Nitekim 1956 Süveyş Krizi Fransa ve İngiltere ile ABD’nin dış politika farklılıklarını su yüzüne çıkarmıştır. Bu kriz sırasında Fransa, İngiltere ve İsrail sürpriz bir saldırıyla işgal ettikleri Süveyş Kanalı bölgesinden ABD ve SSCB’nin ortak tavrı karşısında çıkmak zorunda kalmışlardır. ${ }^{19}$ Söz konusu kriz, yukarıda not edildiği gibi, Fransa ve İsrail'in NS programlarını başlattıkları tarihlerle örtüşmektedir. Öte yandan, NATO'nun kapsamı ve ABD savunma şemsiyesi dışında toprağı ve stratejik hedefleri bulunmayan diğer ülkeler için (örneğin, Kanada) Soğuk Savaş döneminde böyle bir motivasyon oluşmamıştır.

Aynı modele göre, güvenlik riskleri NS sahibi dokuz ülkenin yanı sıra Tablol'deki diğer ülkeler için de etkili olmuştur. Şöyle ki, Nazi Almanya’sı ve Emperyal Japonya NS programlarını 2. Dünya Savaşı sırasında; Güney Kore, İtalya, İsveç, İsviçre ve Tayvan Sovyet tehditlerine karşı ve/veya Nixon Doktrini çerçevesinde bir dönem ABD'nin müttefiklerinden kendi savunmalarını kendilerinin sağlamasını istemesi sebebiyle; Arjantin, Brezilya, Libya, Irak ve Mısır ise artan bölgesel güvenlik riskleri karşısında NS programlarını başlatmışlardır. ${ }^{20}$

15 George P. Schultz, Preventing the Proliferation of Nuclear Weapons, Washington D.C., U.S. Department of State Bulletin, 1984.

16 Michael M. May, "Nuclear Weapons Supply and Demand", American Scientist, Cilt 82, 1994, s.526-37; Bradley Thayer, "The Causes of Nuclear Proliferation and the Nonproliferation Regime", Security Studies Cilt 4, No.3 Spring, 1995, s.463-519; Jo ve Gartzke, "Determinants of Nuclear Weapons Proliferation".

17 Sagan, "Why Do States Build Nuclear Weapons?"; Jo ve Gartzke, "Determinants of Nuclear Weapons Proliferation".

18 Charles De Gaulle, Memoirs of Hope: Renewal and Endeavor, New York, Simon and Schuster, 1971, s.209; David S.Yost, "France's Deterrent Posture and Security in Europe, Part I: Capabilities and Doctrine", Adelphi Paper, No.194, London, International Institute for Strategic Studies, 1984/85, s.4; Jean Lacouture, De Gaulle: The Ruler 1945-1970, New York, W.W. Norton, 1993, s.421.

19 John B. Allcock, "Border and Territorial Disputes", Detroit, Gale Research, 1992.

20 Ibid.; Paul, Power versus Prudence. 
Ancak, Sagan Realist modelin güçlü ve yalın olmasına karşın bütün vakaları tam olarak açıklayamadığını öne sürmektedir. Örneğin, Fransa’nın NS “saplantısı”nın, bu silahların uluslararası sistemdeki sembolik değerinin dikkate alınmasıyla daha iyi anlaşılabileceğinin altını çizmektedir. Alternatif olarak, Sagan tamamlayıcı iki model önermiştir: ulusal ve bürokratik çıkarları merkeze koyan "iç siyaset modeli" ve normatif ve düşünsel unsurları öncelikli gören "normatif model". Bu çerçevede, Çin'in 1964'deki NS testinden sonra Hindistan'ın siyasi karar vericileri arasında NS geliştirme konusundaki fikir ayrılıklarını iç siyaset modeline örnek gösterirken, Güney Afrika'nın nükleer silahlarını imha etmesini nükleer silahsızlanma ve ırksal eşitlik gibi dünyada genel kabul gören fikirleri benimseyerek uluslararası topluma entegre olma isteğine ve dolayısıyla normatif modele destek verici olarak not etmiştir. ${ }^{21}$

Sagan'ın yukarıda belirtilen eleştirilerine karşın bu makale, karar vericiler arasında fikir ayrılıkları olsa dahi, bu tartışmalar sonucunda güvenlik motivasyonu ağır basıyor ve NS programı başlatılıyorsa (Hindistan örneğinde olduğu gibi) Realist modelin geçerliliğini sürdürdüğü görüşünü savunmaktadır. Güney Afrika vakası aşağıda ayrıca tartışılmaktadır.

Realist modele yönelik diğer bir eleştiri ekonomik faktörleri ikinci plana atmasıdır. Most ve Starr, NS sahibi olma isteğinin (talep) yanı sıra firsatın (arz) da NS elde etmede belirleyici olduğunu öne sürmüştür. ${ }^{22} \mathrm{Bu}$ durumda, yeterince firsatın olmaması nükleer yayılmanın önünde arz yönlü bir kısıt olarak ortaya çıkmaktadır. ${ }^{23}$ Jo ve Gartzke, 1939-1992 dönemini nicel yöntemlerle incelemiş ve fırsat kavramını, NS üretmek için gereken maddi ve insani kaynakların (örneğin, uranyum rezervleri, elektrik üretim kapasitesi, enerji ve çelik üretimi) bir bileşimi olarak tanımlamışlardır. Jo ve Gartzke’nin bulguları, güvenlik risklerinin yanı sıra üretim kabiliyetinin NS programını sürdürmede ve ekonomik kapasitenin NS elde etmede güçlü belirleyiciler olduğunu işaret etmektedir. ${ }^{24}$

\section{Nükleer İptalin Belirleyicileri Nelerdir?}

NS programı başlatılmasında ulusal güvenlik riskleri en önemli sebep veya sebeplerden biri ise, barış anlaşmaları, güvenlik garantileri, savunma örgütleri ve diğer yollarla bu risklerin azaltılmasının veya ortadan kaldırılmasının nükleer iptale yol açması ihtimali bulunmaktadır. Öte yandan, bazı devletler kendilerine yönelik sürmekte hatta artmakta olan güvenlik risklerine rağmen NS programlarını sona erdirmişlerdir. NS programlarını silah elde etmeden önce veya elde ettikten sonra (silahlarını imha ederek) sonra erdirmiş devletler Tablo 3’te sınıflandırılmaktadır.

Tablo 3: Nükleer İptal Matrisi

\begin{tabular}{|l|l|l|}
\hline & \multicolumn{1}{|c|}{ Rejim değişikliği var } & \multicolumn{1}{c|}{ Rejim değişikliği yok } \\
\hline $\begin{array}{l}\text { Güvenlik riskleri azaldı/ Güvenlik } \\
\text { garantileri konuldu }\end{array}$ & $\begin{array}{l}\text { Arjantin, Brezilya, Güney } \\
\text { Afrika }\end{array}$ & $\begin{array}{l}\text { İsveç, İsviçre, İtalya, Güney Kore, } \\
\text { Tayvan, (Misır 1979->) }\end{array}$ \\
\hline Güvenlik riskleri sürüyor & Almanya, Japonya & Irak, Libya, Misır \\
\hline
\end{tabular}

21 Sagan, "Why Do States Build Nuclear Weapons?"

22 Most ve Starr, Inquiry, Logic and International Politics.

23 Siverson et.al., "Opportunity, Willingness, and the Diffusion of War."

24 Jo ve Gartzke, "Determinants of Nuclear Weapons Proliferation". 
İlk olarak, Albright Güney Afrika’nın NS programının komşu ülkelerde konuşlandırılmış Sovyet destekli Küba milislerinin meydana getirdiği tehdide karşı güvenlik amaçlı başlatıldığını belirtmektedir. Bu vakada, sahadaki tehdit nükleer bir güç tarafından desteklenmektedir ve Güney Afrika herhangi bir güvenlik şemsiyesi altında bulunmamaktadır. Sonuçta, uluslararası toplumun yaptırımlarına rağmen Güney Afrika 1980'lerin sonuna kadar altı adet NS geliştirmeyi başarmıştır. ${ }^{25}$ Ancak, apartheid rejimini sona erdirme misyonu bulunan Güney Afrika’nın yeni başkanı de Klerk, Küba ve Angola ile 1988'de üçlü antlaşma imzaladıktan sonra ülkenin bütün nükleer silahlarını ve materyallerini, belgeler, fotoğraflar ve teknik çizimler dâhil, imha etme emrini vermiştir. ${ }^{26}$ 1994'de ilk demokratik genel seçimini gerçekleştirdiğinde Güney Afrika artık bütün nükleer silahlarını ortadan kaldırmış ve Nükleer Silahların Yayılmasını Önleme Antlaşması'nı (NSYÖA) imzalamış bulunmaktadır. ${ }^{27}$

Paulkarşılaştırmalıvaka analizinde, GüneyAfrika, Arjantin ve Brezilya’nın nükleer programlarını sona erdirmelerinin bölgesel risklerin büyük ölçüde azalmasının akabinde gerçekleştiğinin altını çizmektedir. ${ }^{28}$ Ayrıca, rejim değişikliğinin nükleer iptale etkisini fazla önemli bulmayan Levite dahi Arjantin ve Brezilya'daki otoriter yönetimlerden demokrasiye geçişlerin bu ülkelerin bölgesel güvenlik ortamlarındaki olumlu gelişmelerle eş zamanlı olduğunu ve nükleer iptalleri öncüllediğini not etmektedir. ${ }^{29}$ Arjantin, Brezilya ve Güney Afrika vakaları güvenlik risklerinin azalmasını ve rejim değişikliğini nükleer iptalde temel sebepler olarak öne çıkarmaktadırlar.

İkinci olarak, Paul İsviçre’nin (program başlatma 1945, iptal 1969) NS geliştirme kapasitesine sahip olduğunu, ama 1960'ların ortalarında genel güvenlik ortamındaki iyileşmeler sebebiyle nükleer iptal yoluna gittiğini belirtmektedir. İsveç (program başlatma 1946, iptal 1969) için de benzer bir durum söz konusudur. ${ }^{30}$ Not etmek gerekir ki, 2. Dünya Savaşı boyunca tarafsızlık politikalarını sürdüren İsveç ve İsviçre'nin, kendilerine karşı tehdit oluşturabilecek Varşova Paktı üyeleri ile aralarında tampon bölge olarak Batı Almanya gibi NATO üyeleri ve/veya Finlandiya ve Avusturya gibi diğer tarafsız devletler yer almıştır. Öte yandan, ABD’nin güvenlik şemsiyesi (NATO veya özel garantiler üzerinden) İtalya, Güney Kore ve Tayvan'ın nükleer iptallerinde belirleyici faktörler olarak öne çıkmaktadır. Güvenlik riskleri sürdügünde ise nükleer iptal için rejim değişikliği kritik rol oynamaktadır. Nazi Almanya'sının ve Emperyal Japonya'nın NS programlarının sona ermesi ancak bu iki ülkenin siyasi rejimlerinin 2. Dünya Savaşı sonunda değişmesiyle gerçeklemiştir. ${ }^{31}$

Realizm tarafından yeterince dikkate alınmamakla birlikte rejim değişikliği, kimlik değişimlerinin devletlerin çıkarlarının tanımlanmasındaki rolünden dolayı, kritik önem arz

25 David Albright, "South Africa and the Affordable Bomb", The Bulletin of the Atomic Scientists, Cilt 50, No. 4, 1994, s.37-47.

26 J.W. de Villiers et.al., "Why South Africa Gave Up the Bomb", Foreign Affairs, Cilt 72, No.5, 1993, s.98-109; Peter Liberman, "The Rise and Fall of the South African Bomb", International Security, Cilt 26, No.2, 2001, s.45-86.

27 F.W. de Klerk, Address to the South African Parliament as Transcribed in Foreign Broadcast Information Service, JPRS-TND-93-009, 29 Mart 1993.

28 Paul, Power versus Prudence.

29 Levite, "Never Say Never Again".

30 Paul, Power versus Prudence; İsviçre NSYÖA'y1 1969'da imzalamış, ancak 1977'ye kadar resmen yürürlüğe koymamıştır.

31 Mevcut verilere göre, Romanya (program 1981, iptal 1989) ve Yugoslavya'nın (program 1953, dondurma 1962, tekrar başlama 1982, iptal 1987) nükleer iptallerinin sebepleri, sırasıyla, Çavuşesku rejiminin sona ermesi ve artan iç istikrarsızlığın rejim değişikliği ve dağılmayla sonuçlanmasıdır. Nuclear Threat Initiative, Nuclear Overview, 2009, http://www.nti.org/e_research/profiles/Yugoslavia/Nuclear/index.html (Erişim Tarihi: 17 Nisan 2015). Jo ve Gartzke, "Determinants of Nuclear Weapons Proliferation". 
etmektedir. ${ }^{32}$ Wendt çok yerinde olarak uluslararası güvenlik açısından nükleer silahların eşit derecede tehdit oluşturmadığını, bu silahlara kimin sahip olduğunun fark yarattığını vurgulamıştır. Örneğin, ABD Fransa ve İngiltere'nin yüzlerce nükleer silahını tehdit olarak algılamazken Kuzey Kore veya İran'ın tek bir nükleer füzesini dahi kabul edilemez görmektedir. ${ }^{33}$ Buna karşın, RF ve Çin, $A B D$ ve müttefiklerinin Kuzey Kore ve İran’a karşı tehdit algılarını paylaşmamakta ve yaptırımlarda boşluklara sebebiyet vermektedirler. ${ }^{34}$ Bir başka örnekte, Şah rejimi döneminde ABD ve İngiltere ile yakın işbirliği kuran İran devleti 1979 devrimi sonrasında dış politikasında temel değişiklikler yaşamıştır. Bu değişim öylesine çarpıcıdır ki, İran’a ilk nükleer teknolojilerin 1970’lerin ortalarında ABD’nin Ford yönetimi tarafindan verilmiş olduğu ve bu yönetimin içinde sonradan George W. Bush kabinesinde yer alacak Dick Cheney ve Donald Rumsfeld’in bulunduğu gerçeği bugün şaşırtıcı bulunabilir. ${ }^{35}$

Güvenlik risklerinin ortadan kalkması ve rejim değişikliği nükleer iptallerin iki önemli belirleyicisi olarak öne çıkarken, literatür giderek yaptırımlara ve arz yönlü kısıtlara odaklanmaktadır. Örneğin, Deutch NS elde etme amacındaki bir devlet için temel problemin yeterli miktarda uranyum veya plütonyum temin etmek olduğunu ifade etmektedir. Bu silahların kullanılmasında devletler, uluslararası silah pazarlarında Çin ve Kuzey Kore gibi aktörlerden balistik füze temin edebilmektedirler. Deutch’a göre her ne kadar NS sahibi olmanın en önemli motivasyonu ulusal güvenliği sağlamaksa da, teknolojik yeterlilikler bu hedefi gerçekleştirme olasılığını ve süresini belirlemektedir. ${ }^{36}$

Kroenig hassas nükleer madde ve teknoloji transferinin nükleer yayılmanın önemli belirleyicilerinden biri olduğunu tespit etmiştir. Ayrıca, NS sahibi devletlerin diğer devletlere kıyasla hassas nükleer madde ve teknoloji transferi yapma olasılıklarının daha yüksek olduğunu ortaya koymuştur. Bu bakımdan, NS devletleri nükleer yayılmaya birincil derecede katkıda bulunmaktadırlar ve stratejikfaktörler (örneğin, ortak düşmanakarşı işbirliğiyapmak) bu süreçtetemel roloynamaktadır. ${ }^{37}$

Fuhrmann sadece hassas maddelerin değil, her türlü sivil amaçlı nükleer teknoloji desteğinin NS yayılması riskini artırdığını not etmiştir. Örneğin, Sovyetler Birliği 1950’lerde Kuzey Kore’ye nükleer bilgiler ve bir araştırma reaktörü vermiş, ABD ise 1960'larda Güney Afrika'ya sivil nükleer destekte bulunmuştur. Fuhrmann ayrıca, NSYÖA’ya taraf olmayan devletlerin, anlaşmanın hedeflerine aykırı olarak, taraf olanlar kadar sivil nükleer destek aldıklarını not etmektedir. ${ }^{38}$ Örneğin, 2005 ABDHindistan nükleer antlaşması ile ABD NSYÖA rejimine taraf olmayan bir ülkeye (Hindistan), "ortak tehdit” Çin'e karşı nükleer yardım sağlamayı kabul etmiştir. Aynı şekilde, Çin de Hindistan'la sınır anlaşmazlığı bulunan Pakistan'a 1990'larda nükleer destekte bulunmuştur. ${ }^{39}$

32 Alexander Wendt, "Anarchy is What States Make of It: The Social Construction of Power Politics", International Organization, Cilt 46, No.2, 1992, s.391-425.

33 Wendt, "Anarchy is What States Make of It".

34 Conor Humphries, Russia Says New EU Sanctions on Iran "Unacceptable”, 27 Temmuz 2010, http://www. reuters.com/article/idUSTRE66Q1PK20100727 (Erişim Tarihi: 10 Nisan 2015).

35 Dafna Linzer, Past Arguments Don 't Square With Current Iran Policy, 27 Mart 2005. http://www.washingtonpost. com/wp-dyn/articles/A3983-2005Mar26.html (Erişim Tarihi: 17 Nisan 2015).

36 John M. Deutch, “The New Nuclear Threat”, Foreign Affairs, No.71, 1991, s.120-134.

37 Matthew Kroenig, "Importing the Bomb: Sensitive Nuclear Assistance and Nuclear Proliferation" Journal of Conflict Resolution, Cilt 53, No.2, 2009, s.161-180; Matthew Kroenig, "Exporting the Bomb: Why States Provide Sensitive Nuclear Assistance", American Political Science Review, Cilt 103, No.1, 2009, s.113-133.

38 Matthew Fuhrmann, "Exporting Mass Destruction? The Determinants of Dual-Use Trade", Journal of Peace Research, Cilt 45, No.5, 2008, s.633-652; Matthew Fuhrmann, "Spreading Temptation: Proliferation and Peaceful Nuclear Cooperation Agreements", International Security, Cilt 34, No.1, 2009, s.7-41. Matthew Fuhrmann, "Taking a Walk on the Supply Side: The Determinants of Civilian Nuclear Cooperation", Journal of Conflict Resolution, Cilt 53, No.2, 2009, s.181-208.

39 Kroenig, "Importing the Bomb"; Fuhrmann, "Spreading Temptation"; Fuhrmann, "Taking a Walk on the Supply Side". 
Bu makale, Kroening ve Fuhrmann'in tespitlerine dayanarak nükleer silahlanmanın daha fazla nükleer yayılmayı sadece talep ayağında değil, arz ayağında da artırdığını öne sürmektedir. Yeni bir NS devletinin ortaya çıkması, artan risk algısı dolayısıyla başka NS programlarını tetiklemenin yanı sıra uluslararası pazarlarda nükleer madde ve teknoloji tedarikçilerinin sayısını da artırmaktadır. ${ }^{40}$ Dahası, yeni NS devletinin ekonomisi yaptırımlarla ne kadar yıpratılmıs ise, elindeki nükleer ürünler için müşteri (özellikle düşmanının düşmanları arasında) arama ve bu maliyetli yatırımından geri dönüş elde etme motivasyonu o kadar kuvvetli olabilecektir. Nitekim Birleşmiş Milletler (BM) denetimcileri 2010'da Kuzey Kore’nin İran ve Myanmar’a nükleer teknoloji ve füze sistemleri sağlamakta olduğunu rapor etmiştir. Kuzey Kore modelini takip eden Myanmar'daki cunta, İran ve Kuzey Kore'nin yanı sıra kendi rejimini "tiranlığın uç noktası” olarak tanımlayan ABD’nin olası bir saldırısına karşı yeraltı kullanım ağı inşa edilmesini emretmiştir. ${ }^{41}$ Netice olarak, potansiyel NS devletleri için stratejik faktörlerin (düşmanlarının düşmanlarından yardım alma) artan şekilde yaptırımları ve arz taraflı kısıtları bertaraf edebileceği ortaya çıkmaktadır. Son olarak, Gartzke ve Kroenig, "devletlerin nükleer silah istemesi eğer bunları elde etme güçleri yoksa önemsizdir” tespitinde bulunmaktadır. ${ }^{42}$

Yukarıda değinilen arz taraflı modeller nicel çalışmalar tarafindan desteklenmektedirler. Ancak, 1990'lı ve 2000'li yıllarda yiyecek ve enerji dış yardımına ihtiyaç duyacak derecede fakir olan ve onlarca yıl boyunca $A B D$ öncülügündeki uluslararası toplumun katı yaptırımlarına maruz kalan Kuzey Kore'nin 2006 yılında NS geliştirmeyi başarması arz taraflı modellere aykırılık oluşturmaktadır (Hindistan ve Pakistan da bu listeye dâhil edilebilir). ${ }^{43}$ Söz konusu süreçte, nicel modellerde dikkate alınmayan dış aktör (örneğin, Pakistan'ın Kuzey Kore’ye) yardımları da rol oynamaktadır. ${ }^{44}$ Ayrıca, Hymans ve Solingen, 2. Dünya Savaşı sonrasında Almanya ve Japonya dâhil pek çok ülkenin NS geliştirme yeterlilikleri olduğu halde bu yolu tercih etmediklerini, dolayısıyla arzın değil talebin en temel etken olduğunu belirtmektedir. ${ }^{45}$

Arz taraflı modellerin geçerliliği konusunda şüphe uyandıran Kuzey Kore vakasının söz konusu modeli savunan araştırmacılar tarafından ele alınışında bir başka yöntemsel kısıt daha bulunmaktadır. Bu çalışmaların kullandığı büyük veri setlerinde Kuzey Kore, örneğin İsveç veya İsviçre gibi tek bir nicel vaka hüviyetindedir. Ancak, niteliksel olarak baktığımızda bu devlet, rejiminin taşıdığı kimlik ve arz ettiği uluslararası güvenlik riskleri açısından diğer pek çok vakadan farklıdır. Bu riskler Kuzey Kore’nin Mart 2010'da bir Güney Kore gemisini torpidoyla batırmasının akabinde NS kullanma tehdidinde bulunmasıyla daha görünür hale gelmiştir. ${ }^{46}$ Dolayısıyla, 2006'ya kadar sadece sekiz NS devletinin bulunduğu uluslararası sistemde Kuzey Kore'yi istatistiksel bir sapmaya indirgemek, bu devletin NS geliştirme şartlarını göz ardı etmemize ve alternatif modelleri doğru değerlendiremememize yol açabilir.

40 Ibid.

41 Bertil Lintner, Myanmar's Nuclear Bombshell, 5 Haziran 2010, http://www.atimes.com/atimes/Southeast_Asia/ LF05Ae01.html (Erişim Tarihi: 17 Nisan 2015).

42 Erik Gartzke ve Matthew Kroenig, "A Strategic Approach to Nuclear Proliferation”, Journal of Conflict Resolution, Cilt 53, No.2, 2009, s.152.

43 Başbakan Butto 1972'de, “Eğer Hindistan [nükleer] bomba geliştirirse, biz çimen veya yaprak yeriz, hatta aç gezeriz, ama kendimizinkini de geliştiririz" demiştir. Bkz. Cirincione, Bomb Scare.

44 Alexander Montgomery, "Ringing in Proliferation”, International Security, Cilt 30, No.2, 2005, s.153-187.

45 Hymans, The Psychology of Nuclear Proliferation; Etel Solingen, "The Political Economy of Nuclear Restraint", International Security, Cilt 19, No.2, 2007, s.126-169.

46 "North Korea Issues Threats as U.S. Leads Exercises", USA Today, 25 Temmuz 2010, http://www.usatoday. com/news/world/2010-07-23-us-northkorea-nuclear-meet_N.htm (Erişim Tarihi: 18 Nisan 2015). 
Yukarıdaki analizler ışığında, NS programlarının silah elde etme ile sonuçlanmasına yola açan etkenler arasında ulusal güvenlik risklerinin devamı ve rejim sürekliliği öne çıkmaktadır: NS elde etme motivasyonu ve devamlılığı bulunan bir rejim, ülkenin kaynakları kıt olsa dahi nükleer programına öncelik vererek NS elde edebilmektedir. ${ }^{47} \mathrm{Ayn}$ ı şekilde, bölgesel güvenlik ortamının iyileşmesi veya güvenlik garantilerinin konulmasına bağlı olarak risklerin azaldığı durumlarda veya rejim değişikliği gerçekleştiğinde NS programlarının sona erdirildiği görülmektedir. Ancak, Tablo 3'te de belirtildiği üzere, ulusal güvenlik riskleri süren ve rejim değişikliği olmayan halde üç vakada NS programlarının iptal edildiği tespit edilmiştir. Söz konusu "aykırı” vakalar: Mısır (program başlangıcı 1955, program iptali 1973), Libya (program 1978, iptal 2003) ve Irak (program 1973, iptal 1991) şeklindedir.

\section{Mısır}

Mısır'ın nükleer programı 1955'te İsrail ile aynı yılda başlamış, 1960'larda İsrail'in kendi programında belirgin gelişmeler kaydetmesine paralel olarak hızlanmıştır. İsrail'in yeni bir nükleer reaktör inşa ettiğini ilan etmesinin akabinde Mısır Devlet Başkanı Nasır, eğer İsrail NS geliştirse kendilerinin de ne pahasına olursa olsun geliştireceklerini beyan etmiştir. Bununla birlikte, Mısır SSCB'den veya Çin'den nükleer teknolojiler ve NS satın alma konusunda başarılı olamamıştır. ${ }^{48}$

Einhorn Mısır’n 1967'deki 6 Gün Savaşı’nı kaybetmesinin nükleer programında kritik bir dönüşe yol açtığını öne sürmektedir. ${ }^{49}$ İsrail 1967'deki Altı Gün Savaşı’nda Mısır, Suriye ve Ürdün'e karşı sürpriz bir saldırı başlatmış ve önce bu ülkelerin hava kuvvetlerini imha etmiştir. Bir kere hava üstünlüğ̈nü sağladıktan sonra İsrail bu ülkelerin zırhlı birliklerine ve deniz kuvvetlerine ağır kayıplar verdirmiş, Mısır'dan Sina Yarımadası'nı, Suriye'den ise Golan Tepeleri’ni almıştır. Savaştan sonra Süveyş Kanalı'na ve Sina petrolüne erişimini kaybeden Mısır, savunma harcamalarını ve stratejik önceliklerini nükleer programdan konvansiyonel silahlanmaya kaydırmıştır.

1973’teki Yom Kippur Savaşı’nda bu sefer Mısır ve Suriye İsrail’e sürpriz saldırı düzenlemiş, ancak İsrail ABD’nin acil silah ve mühimmat yardımıyla toparlanarak Arap ordularını geri püskürtmeyi başarmıştır. ${ }^{50} 1973$ 'te İsrail'e karşı askeri başarı sağlayamamasının ardından Mısır NS programını sona erdirmiştir. Levite Mısır'ın NS programını sona erdirme kararının arkasında, programın maliyetinin yanı sıra İsrail'in caydırıcı politikalarının ve ABD'nin güvenlik garantilerinin bulunduğunu savunmaktadir. ${ }^{51}$

Teorik olarak, Mısır İsrail kaynaklı güvenlik risklerine karşı NS programını başlatmış ise, bu ülkenin İsrail’e karşı 1967 ve 1973 yıllarında aldığı askeri yenilgiler karşısında nükleer iptal yoluna gitmiş olması arz talepli modele destek verebilir (örneğin, petrol kaynaklarının azalması sebebiyle) ve bu makalenin savunduğu teze (ulusal güvenlik risklerinin NS talebinde en önemli etkenlerden biri

47 Örnegin, Kuzey Kore GSMH'nin \%25'ini savunmaya ayırmıştır. Cirincione, Bomb Scare.

48 Robert J. Einhorn, "Egypt: Frustrated but Still on a Non-Nuclear Course", Kurt M. Campbell et.al. (der.), The Nuclear Tipping Point: Why States Reconsider Their Nuclear Choices, Washington, D.C., Brookings Institution Press, 2004, s.43-82.

49 Ibid.

50 Robert L. Butterworth ve Margaret E. Scranton, Managing Interstate Conflict, 1945-74: Data with Synopses, Pittsburgh, University Center for International Studies, University of Pittsburgh Press, 1976; Allcock, "Border and Territorial Disputes"; James Ciment, Encyclopedia of Conflicts since World War 2, New York, Sharpe Reference, 1999; Chris Cook ve Whitney Walker, The Facts on File World Political Almanac: from 1945 to the Present, New York, Facts on File, 2001; Micheal Clodfelter, Warfare and Armed Conflicts: A Statistical Reference to Casualty and Other Figures, 1500-2000, Jefferson, McFarland \& Co., 2002.

51 Levite, "Never Say Never Again". 
olduğuna) aykırılık oluşturur. Çünkü tezimiz doğruysa, ulusal güvenlik riskleri ve siyasi rejim sürdüğü müddetçe NS programının devam ettirilmesi beklenmektedir. ${ }^{52}$

$\mathrm{Bu}$ makalenin tezi açısından yukarıda işaret edilen aykırılığın açıklanması, konvansiyonel ve nükleer silahlanma arasındaki hiyerarşik yapının anlaşılmasıyla mümkün olabilir. Mısır'ın 1967 ve 1973'te konvansiyonel silahlarını büyük ölçüde kaybetmesi, ulusal güvenliğini sağlaması açısından nükleer yerine konvansiyonel silahlanmaya öncelik vermesini gerektirmiştir. Şöyle ki, nükleer silahların aksine konvansiyonel silahlar devletlerin güvenliğini sadece diğer ülkelere karşı savunmalarına katkıda bulunmakla kalmaz, sınırlarını denetleme (örneğin, terörist gruplara karşı) ve dış hedeflere sınırlı askeri operasyonlar düzenleme gibi işlevleri de yerine getirirler. Bunlara ek olarak, Mısır'da olduğu gibi anti-demokratik rejimlerin sürekliliğini sağlayan önemli bir unsur, konvansiyonel silahların toplumsal isyanları bastırma ve iç muhalefete karşı iktidarı sürdürmedeki işlevidir. Nitekim bu makalenin yazım tarihi itibariyle dünyadaki iki yüze yakın ülkenin dokuzu hariç hiçbiri NS sahibi değildir ama konvansiyonel silahlı güçleri bulunmaktadır. Ordularını lağvetmiş Kosta Rika, Mauritius ve diğer bazı küçük ülkeler dahi sınır kontrolü ve iç güvenlik sebepleriyle sahil güvenlik ve yarı askeri birimler bulundurmaktadırlar. Öte yandan, söz konusu dokuz ülke NS geliştirdikten sonra da konvansiyonel güçlerini muhafaza etmeye devam etmişlerdir.

Sonuç olarak bu makale, İsrail'in 1967 ve 1973'te Mısır'ın hava, deniz ve kara kuvvetlerine verdirdiği ağır kayıpların doğurduğu ulusal güvenlik risklerinin, yaptırımlar ve arz taraflı kısıtlar ile birlikte, Mısır'ın NS programını durdurmadaki en önemli faktör olduğunu öne sürmektedir. Öte yandan, Mısır takip eden yıllarda konvansiyonel askeri gücünü yeniden kurduktan sonra NS programını tekrar başlatmamıştır. Bunun sebebi, 1978 Camp David görüşmeleri ve 1979 Mısırİsrail Antlaşması sonucunda İsrail'in Sina Yarımadası'nı silahsız kalması şartıyla Mısır'a geri vermesi ve $A B D$ 'nin bu anlaşmayı askeri ve ekonomik yardımlar ile desteklemesidir. Bu noktada Mısır artık Tablo 3 'teki “Güvenlik riskleri sürüyor” kategorisinden "Güvenlik riskleri azaldı / güvenlik garantileri konuldu” kategorisine geçmiştir. Söz konusu anlaşma halen geçerliliğini korumaktadır.

\section{Libya}

Libya NS silah programını 1978 yılında, Mısır’a karşı askeri mağlubiyetinden 1 yıl sonra başlatmış ve ABD-Batı Avrupa ile ilişkilerinin gerginleştiği 1980’lerde sürdürmüştür. Terörist gruplara destek verdiği iddialarının yanı sıra kitle imha silahları elde etmek için gösterdiği yoğun çaba nedeniyle Libya 1980’lerden başlayarak ağır yaptırımlara maruz kalmıştır. ${ }^{53}$ Yirmi yıldan fazla süren bu yaptırımlardan sonra Libya Aralık 2003'te nükleer, biyolojik ve kimyasal silah programlarını sona erdirmeye karar verdiğini ilan etmiştir. Bu kararın akabinde birçok uzman, yaptırımların doğurduğu arz taraflı kısıtların Libya’nın NS elde etmesini engellemedeki en önemli etken olduğunu ileri sürmüşlerdir. ${ }^{54}$

Bu makale Libya vakasında da arz taraflı kısıtların değil, ulusal güvenlik risklerinin NS programı iptalinde en önemli rolü oynadığı görüşünü savunmaktadır. Şöyle ki, Libya'nın nükleer iptali ABD’nin Irak'ı sözde NS programından ve terörist bağlantılarından ötürü suçlayarak işgal ettiği tarihe denk

52 Nasır öldükten sonra fiili tek parti iktidarı Nasır'ın başkan yardımcısı Enver Sedat başkanlığında devam etmiştir.

53 Andrea Koppel ve Elise Labott, U.S. to Lift Final Sanctions Against Libya, 17 Eylül 2004, http://www. cnn.com/2004/WORLD/africa/09/17/us.libya/index.html (Erişim Tarihi: 17 Nisan 2015; "Libyan Nuclear Weapons", Global Security, 2008, http://www.globalsecurity.org/wmd/world/libya/nuclear.htm (Erişim Tarihi: 7 Nisan 2015).

54 Jo ve Gartzke, "Determinants of Nuclear Weapons Proliferation". 
gelmektedir. ABD'nin Libya'ya yönelik açık tehdidi ise Ekim 2003'te ABD donanmasının Libya'ya gitmekte olan ve uranyum zenginleştirmeye yönelik binlerce teknik parçayı ele geçirmesiyle zirveye çımıştır. ${ }^{55} \mathrm{Bu}$ tehditlere ek olarak Libya rejimi nezdinde, ABD'nin olası bir askeri saldırısının Libya'nın kara, hava ve deniz kuvvetlerini imha edeceği ve Kaddafi rejiminin sonunun da muhtemelen Saddam rejimi gibi olacağı endişesi doğurmuş olması kuvvetle muhtemeldir. ${ }^{56}$ Yine not edilmelidir ki, Libya tesislerini nihayet açtığında BM denetçileri bu ülkenin NS programının ileri safhası karşısında hayrete düşmüşlerdir. ${ }^{57}$ Sonuç olarak, bu makale sebep-sonuç ilişkisini kurarken, yirmi yıl süren yaptırımların ve arz taraflı kısıtların 2003 'te birden bire, hem de NS programı ileri bir safhaya varmışken işe yaramış olduğu açıklaması yerine, ABD'nin o tarihteki caydırıcı ve Irak'ta gerçekleştirilmiş askeri tehdidinin Libya’nın NS programının iptalinde ana belirleyici etken olduğu görüşünü gerçekçi bulmaktadır.

\section{Irak}

Irak'ın NS programının başlangıç tarihi (1973) üzerinde literatürde genel olarak fikir birliği bulunmakla birlikte, bazı çalışmalarda verilen iptal tarihi (2002) sahadan gelen veriler ile çelişmektedir. ${ }^{58}$ NATO'nun 2002'de Afganistan'ı işgalinden sonra ABD Irak’a toplu imha silahlarıyla ilgili denetim talebinde bulunmuştur. Buna mukabil Irak ABD’nin olası müdahalesini engelleyebilmek için Kasım 2002'de, sonradan Libya'nın Aralık 2003'te yapacağı gibi, BM’nin tam denetimine razı olmuştur. Ancak, ABD yönetimi bu kararı yetersiz ve çok geç olarak niteleyerek işgal yolunu seçmiştir. ${ }^{59}$ Irak' 'n 2003 'teki işgalinden sonra BM denetçileri ve ABD Irak’ın NS programının 1990-91'deki 1. Körfez Savaşı'nın hemen ertesinde sona ermiş olduğunu tespit etmişlerdir. ${ }^{60}$

Deutch Irak'ın NS programının uzun yıllar Almanya'dan satın alınan çift amaçlı teknolojiler sayesinde sürebilmiş olduğunun altını çizmektedir. Deutch, "Birleşmiş Milletler’in yaptırımları ve $\mathrm{ABD}$ ile diğer ülkelerin istihbaratları tarafından tümüyle donatılmış olmasına karşın Uluslararası Atom Enerji Ajansı (UAEA) Irak'ın nükleer tesislerinin yerini bulmak ve denetlemek konusunda belirgin güçlük yaşamıştır." demektedir. ${ }^{61}$ Buna paralel olarak, Nye Irak'ın NS programının, geçmiş UAEA denetimleri ve NSYÖA rejiminin etkinliği konusunda ciddi şüpheler doğurduğunu not etmektedir. Nye, "Eğer politikanın amacı her tür [nükleer] teknolojinin yayılmasını önlemek ise durum ümitsizdir. Ama eğer politikanın amacı teknolojilerin yayılma hızını azaltarak istikrarsızlaştırıcı etkilerini yönetmek ise, belirgin başarı elde edilmiştir” yorumunu yapmaktadır. ${ }^{62}$

Irak vakası sınırlı önleyici saldırıların etkinliği konusunda da şüphe uyandırmaktadır. Çalışmalar, İsrail 1981'de Irak'ın Osirak nükleer reaktörünü vurduktan sonra Irak'ın NS programını iptal etmediğini, tersine hızlandırdığını göstermektedir. ${ }^{63}$ Öte yandan, Irak'ın Ağustos 1990 'da Kuveyt 'i işgal etmesinden sonra ABD liderliğindeki uluslararası koalisyon Çöl Fırtınası Operasyonu'nu başlatmış

\footnotetext{
55 "Libyan Nuclear Weapons".

56 Nitekim bu senaryo 2011'de NATO'nun Libya'ya müdahale etmesiyle gerçeklemiştir.

57 Cirincione, Bomb Scare.

58 Jo ve Gartzke, Codebook and Data Notes

59 Mohammed ElBaradei, The Status of Nuclear Inspections in Iraq: An Update, 2003, http://www.iaea.org/ NewsCenter/Statements/2003/ebsp2003n006.shtml (Erişim Tarihi: 7 Nisan 2015). Cirincione, Bomb Scare.

60 Ibid.

61 Deutch, "The New Nuclear Threat", s.127.

62 Joseph S. Nye, Jr., "New Approaches to Nuclear Proliferation Policy”, Science New Series Cilt 256, No.5061, 1992, s.1293.

63 Malfrid Braut-Hegghammer, Can an Attack Deny Iran the Bomb?, 11 Haziran 2009. http://www.huffingtonpost. com/malfrid-brauthegghammer/can-an-attack-deny-iran-t_b_572162.html (Erişim Tarihi: 15 Nisan 2015).
} 
ve Irak'ın askeri üslerini, havaalanlarını, sevk ve idare merkezlerini, sanayi ve petrol tesislerini, füze rampalarını ve ulaşım ile haberleşme altyapılarını hedef almıştır. Savaş sonrasında Irak üzerine ciddi yaptırımlar uygulanmıştır. ${ }^{64}$

Sonuç olarak, Irak'ın NS programının iptali, konvansiyonel güçlerinin 1990-91 savaşında büyük ölçüde imha olmasının akabinde gerçekleşmiş, takip eden yaptırımlar ve Birleşmiş Milletler Özel Komisyonu'nun (UNSCOM) 1991'de başlayan kontrolleriyle bu ülke üzerinde yoğun baskı sürmüştür. Savaş sonrası Saddam rejimi hem sınırlarını, hem de iç muhalefete karşı anti-demokratik yönetimini koruyabilmek için önceliğini konvansiyonel silahlanmaya kaydırmıştır. Bu suretle Mısır ve Libya vakalarında olduğu gibi bir kere daha, arz taraflı kısıtların ancak askeri tehdit ile birlikte kullanıldığında istenilen sonucu verdiği görülmektedir.

\section{İran'ın Nükleer Programının Geleceği}

NSYÖA'yı 1968 yılında imzalamış olan İran, UAEA tarafından bu antlaşmanın gereklerini yerine getirmediği gerekçesiyle 2003 yılı raporunda eleştirilmiştir. ${ }^{65}$ Uluslararası kamuoyunun İran konusundaki endişeleri, bu ülkenin Eylül 2009'da Kum şehri yakınlarındaki bir dağın içinde gizli nükleer tesisinin keşfedilmesiyle ve Kasım 2009'da on yeni uranyum zenginleştirme tesisi inşa emrini vermesiyle daha da güçlenmiştir. ${ }^{66}$ Nitekim İran tarafından KOEP metninde kabul edildiği üzere, bu ülkenin zenginleştirilmiş uranyum rezervi, enerji amaçlı ihtiyacının (\%3.67) çok üzerindedir (\%20). ${ }^{67}$

Not etmek gerekir ki, ABD’nin 2003 yılında bölgeye yönelik askeri tehditleri, Avrupa Birliği’yle yürütülen görüşmelerin ve iç siyasi gelişmelerin etkileriyle birlikte, İran üzerinde de tesirli olmuştur. İran'ın bütün uranyum zenginleştirme ve dönüştürme faaliyetlerini askıya aldığını ilan etmesi, ABD öncülüğünde yapılan Irak işgalini müteakip Ekim 2003'te gerçekleşmiştir. ${ }^{68}$ İran nükleer programı, Amerikan kamuoyunun savaşa verdiği desteğin Afganistan ve Irak’taki asker kayıplarına bağlı olarak düştüğ̈̈ 2005-2006 yıllarında tekrar başlamıştır. ${ }^{69}$

AB3+3'ün 14 Temmuz 2015 tarihinde İran ile imzaladığı KOEP, İran'ın yukarıda belirtilen NS geliştirme koşullarını ve motivasyonlarını hepten ortadan kaldırmamaktadır. Şöyle ki, 1979 Mısırİsrail Antlaşması'nın aksine KOEP, İran'ın ABD'ye ve özellikle de bu anlaşmanın tarafı olmayan İsrail'e yönelik güvenlik tehdidi algılarında kapsamlı bir değişiklik yaratmamaktadır. Ayrıca, özellikle Irak ve Suriye'de ortaya çıkan DAEŞ/IŞİD tehdidi İran için bölgesel güvenlik risklerinin artması olarak yorumlanabilir. Son olarak, KOEP İran'ın bilinen nükleer tesislerini ve faaliyetlerini denetim altına

64 Butterworth ve Scranton, Managing Interstate Conflict; Allcock, "Border and Territorial Disputes"; Ciment, Encyclopedia of Conflicts since World War 2; Cook ve Walker, The Facts on File World Political Almanac; Clodfelter, Warfare and Armed Conflicts.

65 IAEA, "Implementation of the NPT safeguards agreement in the Islamic Republic of Iran," 19 Haziran 2003, Report by the Director General GOV/2003/40.

66 "Iran 'Planning 10 New Uranium Enrichment Sites”, BBC News, 29 Kasim 2009, http://news.bbc.co.uk/2/hi/ middle_east/8385275.stm (Erişim Tarihi: 5 Nisan 2015); Sanger ve Broad, Agencies Suspect Iran is Planning Atomic Sites.

67 Ibid, Madde 7, s. 8.

68 IAEA, IAEA and Iran. Statement by the Iranian Government and Visiting EU Foreign Ministers, 2003, http:// www.iaea.org/NewsCenter/Focus/IaeaIran/statement_iran21102003.shtml (Erişim Tarihi: 10 Nisan 2015).

69 Cirincione, Bomb Scare; Joseph M. Grieco et.al., Let's Get a Second Opinion: International Institutions and American Public Support for War, 2007, http://iicas.ucsd.edu/papers/PIA/gelpi_paper.pdf(Erişim Tarihi: 10 Nisan 2015); David E. Sanger ve William J. Broad, Agencies Suspect Iran is Planning Atomic Sites, 27 Mart 2010. http:// www.nytimes.com/2010/03/28/world/middleeast/28nuke.html?_r=1\&hp (Erişim Tarihi: 17 Nisan 2015). 
almakta ve bunun karşılığına İran ekonomisi üzerindeki yaptırımları kademeli olarak gevşetmektedir. Buna karşın, bilinmeyen ama istihbaratlar doğrultusunda ileride inceleme talep edilebilecek tesisler için uyuşmazlık çözümüne yönelik ve başarısızlık halinde yaptırımları geri getirecek bir mekanizma oluşturulmaktadır. İran'ın anlaşmaya uymaması durumunda KOEP yürürlükten kalkacak, ancak İran'ın azalan yaptırımlardan o güne kadar sağlayacağı kazanımlar baki kalacaktır.

Bu makaledeki analizler ışığında, İran'ın NS geliştirmek için gerekli motivasyona ve koşullara fazlasıyla sahip olduğu görülmektedir. Şöyle ki, Şah rejimi sırasında ilk nükleer teknolojilerini ABD’den alan İran (1) 1979'deki rejim değişikliğinden itibaren, her ikisi de NS sahibi olan ABD ve İsrail'i güvenlik tehditleri olarak algılamıştır ve (2) NS geliştirmek için gereken rejim sürekliliğine sahiptir. Bunlara ek olarak, İran (3) NS gelişmeyi başarmış Kuzey Kore'den çok daha zengin kaynaklara (özellikle petrol ve doğal gaz) sahiptir ve (4) güvenlik bürokrasisini NS elde etmekten alıkoyacak güçte bir iç muhalefet veya halk hareketi bulunmamaktadır. Öte yandan, yaptırımlar, arz taraflı kısıtlar, normlar ve NSYÖA rejimi İran'ı nükleer programında ciddi mesafe almaktan alıkoyamamıştır. ${ }^{70}$

\section{Sonuç}

Karşılaştırmalı vaka analizlerine dayanan bu makale, ulusal güvenlik risklerinin ve rejim değişikliğinin nükleer iptallerde en belirleyici etkenler olduğunu ortaya koymaktadır. Öte yandan, yaptırımlar, arz taraflı kısıtlar, normlar ve NSYÖA rejimi tek başlarına Güney Afrika, İsrail, Hindistan, Pakistan ve Kuzey Kore'yi NS geliştirmekten alıkoyamamıştır. Mısır, Irak ve Libya'nın NS programlarını sona erdirmeleri, ancak yaptırımlar ve arz taraflı kısıtlar caydırıcı askeri tehditler ile tamamladığında gerçekleşmiştir. Bu bakımdan, rejim sürekliliğinin olduğu devletlere uygulanan yaptırımlar, nükleer madde ve teknolojilere erişimin tamamen sınırlanamadığı günümüzde NS geliştirmeyi sadece geciktirmeye yaramaktadır.

$\mathrm{Bu}$ analizler ışığında makalenin vardığı sonuç, AB3+3’ün Temmuz 2015'te İran ile imzaladığı KOEP'in, İran'ın NS geliştirme motivasyonunu ve koşullarını ortadan kaldırmadığı şeklindedir. İran'ın bölgesel güvenlik algılamasında bir iyileşme olmadığı gibi (NS sahibi İsrail KOEP’in tarafı değildir), görece yakın zamanda ortaya çıkan DAEŞ/IŞİD tehdidi ve İran'ın yakın işbirliği yaptığı Suriye rejiminin askeri kırılganlığı İran için risk artırıcı etkenler olarak kabul edilebilir. Sonuç olarak, 1979 Mısır-İsrail Antlaşması gibi güvenlik garantileri içermeyen KOEP’in İran'ı NS edinme eşiğinden uzun vadeli olarak uzak tutma potansiyeli, İran ulusal güvenlik risklerinde önemli bir azalma yaşamadığı müddetçe gerçekçi görülmemektedir.

70 Jeffrey Berejikian ve Matthew Fuhrmann, "Disaggregating Noncompliance: Exit and Predation in the Nonproliferation Regime" Konferans sunum, 28 Mart 2007, http://ssrn.com/abstract=1367382 (Erişim Tarihi: 12 Ekim 2010). 


\section{Kaynakça}

Albright, David. "South Africa and the Affordable Bomb", The Bulletin of the Atomic Scientists, Cilt July/August, 1994, s.37-47.

Allcock, John B. “Border and Territorial Disputes”, Detroit, MI: Gale Research, 1992.

Beardsley, Kyle ve Victor Asal. "Winning the Bomb”, Journal of Conflict Resolution, Cilt 53, No.2, 2009, s. 278-301.

Berejikian, Jeffrey ve Matthew Fuhrmann. "Disaggregating Noncompliance: Exit and Predation in the Nonproliferation Regime” Konferans sunum, 28 Mart 2007, http://ssrn.com/abstract=1367382 (Erişim Tarihi: 12 Ekim 2009).

Braut-Hegghammer, Malfrid. Can an Attack Deny Iran the Bomb?, 11 Haziran 2009. http://www.huffingtonpost. com/malfrid-brauthegghammer/can-an-attack-deny-iran-t_b_572162.html (Erişim Tarihi: 15 Nisan 2015).

Butterworth, Robert L. ve Margaret E. Scranton. Managing Interstate Conflict, 1945-74: Data with Synopses, Pittsburgh, PA: University Center for International Studies, University of Pittsburgh Press, 1976.

Campbell, Kurt M. ve Robert J. Einhorn. “Avoiding the Tipping Point: Concluding Observations”, Kurt M. Campbell, Robert J. Eihnorn ve Mitchell B. Reiss (der.), The Nuclear Tipping Point: Why States Reconsider Their Nuclear Choices, Washington, D.C.: Brookings Institution Press, 2004, s. 317-45.

Ciment, James. Encyclopedia of Conflicts since World War 2, New York, Sharpe Reference, 1999.

Cirincione, Joseph. Bomb Scare: The History and Future of Nuclear Weapons, New York, Columbia University Press, 2007.

Clodfelter, Michael. Warfare and Armed Conflicts: A Statistical Reference to Casualty and Other Figures, 15002000, Jefferson, NC, McFarland \& Co., 2002.

Cook, Chris ve Whitney Walker. The Facts on File World Political Almanac: from 1945 to the Present, New York, Facts on File, 2001.

De Gaulle, Charles. Memoirs of Hope: Renewal and Endeavor, New York, Simon and Schuster, 1971.

De Klerk, Frederik W. Address to the South African parliament as transcribed in Foreign Broadcast Information Service, JPRS-TND-93-009, 29 Mart 1993.

De Villiers, J.W., Roger Jardine ve Mitchell Reiss. "Why South Africa Gave Up the Bomb”, Foreign Affairs, Cilt 72, No.5, November/December, 1993, s.98-109.

Deutch, John M. “The New Nuclear Threat”, Foreign Affairs, No.71, 1991, s.120-134.

Einhorn, Robert J. "Egypt: Frustrated but Still on a Non-Nuclear Course”, Campbell, Eihnorn ve Reiss, The Nuclear Tipping Point, s.43-82.

ElBaradei, Mohammed. The Status of Nuclear Inspections in Iraq: An Update, 2003, http://www.iaea.org/ NewsCenter/Statements/2003/ebsp2003n006.shtml (Erişim Tarihi: 7 Nisan 2015).

Fuhrmann, Matthew. "Exporting Mass Destruction? The Determinants of Dual-Use Trade", Journal of Peace Research, Cilt 45, No.5, 2008, s.633-652.

Fuhrmann, Matthew. "Spreading Temptation: Proliferation and Peaceful Nuclear Cooperation Agreements", International Security, Cilt 34, No.1, 2009, s.7-41.

Fuhrmann, Matthew. "Taking a Walk on the Supply Side: The Determinants of Civilian Nuclear Cooperation”, Journal of Conflict Resolution, Cilt 53, No.2, 2009, s.181-208.

Gartzke, Erik ve Matthew Kroenig. “A Strategic Approach to Nuclear Proliferation”, Journal of Conflict Resolution, Cilt 53, No.2, 2009, s.151-160.

Grieco, Joseph M., Christopher Gelpi, Jason Reifler ve Peter D. Feaver. Let's Get a Second Opinion: International Institutions and American Public Support for War, 2007, http://iicas.ucsd.edu/papers/PIA/gelpi_paper.pdf (Erişim Tarihi: 10 Nisan 2015).

Holloway, David. The Soviet Union and the Arms Race, New Haven, CT, Yale University Press, 1980. 
Humphries, Conor. Russia Says New EU Sanctions on Iran "Unacceptable", 27 Temmuz 2010, http://www. reuters.com/article/idUSTRE66Q1PK20100727 (Erişim Tarihi: 10 Nisan 2015).

Hymans, Jacques E.C. The Psychology of Nuclear Proliferation, Cambridge, Cambridge University Press, 2006.

IAEA, IAEA and Iran. Statement by the Iranian Government and Visiting EU Foreign Ministers, 2003, http:/ / www. iaea.org/NewsCenter/Focus/IaeaIran/statement_iran21102003.shtml (Erişim Tarihi: 10 Nisan 2015).

“Iran 'Planning 10 New Uranium Enrichment Sites’”, BBC News, 29 Kasım 2009, http://news.bbc.co.uk/2/hi/ middle_east/8385275.stm (Erişim Tarihi: 5 Nisan 2015).

JCPOA (Joint Comprehensive Plan of Action), 14 Temmuz 2015, http://eeas.europa.eu/statements-eeas/ docs/iran_agreement/iran_joint-comprehensive-plan-of-action_en.pdf (Erişim Tarihi: 22 Temmuz 2015).

Jo, Dong-Joon ve Erik Gartzke. “Determinants of Nuclear Weapons Proliferation”, Journal of Conflict Resolution, Cilt 51, No.1, 2007, s.167-194.

Jo, Dong-Joon ve Erik Gartzke. Codebook and Data Notes for "Determinants of Nuclear Weapons Proliferation: A Quantitative Model. 2006, http://www.columbia.edu/ eg589/ (Erişim Tarihi: 10 Nisan 2015).

Koppel, Andrea ve Elise Labott. U.S. to Lift Final Sanctions Against Libya, 17 Eyül 2004, http://www.cnn. com/2004/WORLD/africa/09/17/us.libya/index.html (Erişim Tarihi: 17 Nisan 2015).

Kroenig, Matthew. "Exporting the Bomb: Why States Provide Sensitive Nuclear Assistance”, American Political Science Review, Cilt 103, No.1, 2009, s.113-133.

Kroenig, Matthew. “Importing the Bomb: Sensitive Nuclear Assistance and Nuclear Proliferation” Journal of Conflict Resolution, Cilt 53, No.2, 2009, s.161-180.

Lacouture, Jean. De Gaulle: The Ruler 1945-1970, New York, W.W. Norton, 1993, s.421.

Levite, Ariel E. “Never Say Never Again”, International Security, Cilt 27, No.3, 2002, s.59-88.

Liberman, Peter. "The Rise and Fall of the South African Bomb”, International Security, Cilt 26, No.2, 2001, s.45-86.

"Libyan Nuclear Weapons", Global Security, 2008, http://www.globalsecurity.org/wmd/world/libya/nuclear. htm (Erişim Tarihi: 7 Nisan 2015).

Lintner, Bertil. Myanmar's Nuclear Bombshell, 5 Haziran 2010, http://www.atimes.com/atimes/Southeast_ Asia/LF05Ae01.html (Erişim Tarihi: 17 Nisan 2015).

Linzer, Dafna. Past Arguments Don't Square With Current Iran Policy, 27 Mart 2005. http://www.washingtonpost. com/wp-dyn/articles/A3983-2005Mar26.html (Erişim Tarihi: 17 Nisan 2015).

May, Michael M. "Nuclear Weapons Supply and Demand”, American Scientist, Cilt 82, 1994, s.526-37.

Miller, Steven E. “The Case Against a Ukrainian Nuclear Deterrent”, Foreign Affairs, Cilt 72, No.3, 1993, s.67-80.

Montgomery, Alexander. "Ringing in Proliferation”, International Security, Cilt 30, No.2, 2005, s.153-187.

Most, Benjamin A. ve Harvey Starr. Inquiry, Logic and International Politics, Columbia, SC, University of South Carolina Press, 1989.

"North Korea Issues Threats as U.S. Leads Exercises", USA Today, 25 Temmuz 2010, http://www.usatoday. com/news/world/2010-07-23-us-northkorea-nuclear-meet_N.htm (Erişim Tarihi: 18 Nisan 2015).

Nuclear Threat Initiative, Nuclear Overview, 2009, http://www.nti.org/e_research/profiles/Yugoslavia/ Nuclear/index.html (Erişim Tarihi: 17 Nisan 2015).

Nye Jr., Joseph S. "New Approaches to Nuclear Proliferation Policy”, Science New Series Cilt 256, No.5061, 1992, s.1293-1297.

Paul, T.V. Power versus Prudence: Why nations forgo nuclear weapons, Montreal, McGill-Queens University Press, 2000.

Sagan, Scott D. "Why Do States Build Nuclear Weapons? Three Models in Search of a Bomb”, International Security, Cilt 21, No.3, 1996/97, s.54-86. 
Sanger, David E. ve William J. Broad. Agencies Suspect Iran is Planning Atomic Sites, 27 Mart 2010. http://www. nytimes.com/2010/03/28/world/middleeast/28nuke.html?_r=1\&hp (Erişim Tarihi: 17 Nisan 2015).

Schultz, George P. Preventing the Proliferation of Nuclear Weapons, Washington D.C., U.S. Department of State Bulletin, 1984.

Siverson, Randolph M. ve Harvey Starr. “Opportunity, Willingness, and the Diffusion of War”, American Political Science Review, Cilt 84, No.1, 1990, s.47-67.

Solingen, Etel. “The Political Economy of Nuclear Restraint”, International Security, Cilt 19, No.2, 2007, s.126169.

Thayer, Bradley. "The Causes of Nuclear Proliferation and the Nonproliferation Regime", Security Studies Cilt 4, No. 3, Spring, 1995, s.463-519.

Wendt, Alexander. "Anarchy is What States Make of It: The Social Construction of Power Politics", International Organization, Cilt 46, No.2, 1992, s.391-425.

Yost, David S. "France's Deterrent Posture and Security in Europe, Part I: Capabilities and Doctrine”, Adelphi Paper, No.194, London, International Institute for Strategic Studies, 1984/85. 